Marquette University

e-Publications@Marquette

Theology Faculty Research and Publications

Theology, Department of

$1-1-1997$

Effects of Variant Narrators in Acts 10-11

William Kurz

Marquette University, william.kurz@marquette.edu

Published Version. New Testament Studies, Vol. 43, No. 1 (October, 1997): 570-586. DOI. C 1997 Cambridge University Press. Used with permission. 


\title{
EFFECTS OF VARIANT NARRATORS IN ACTS 10-11
}

\author{
WILLIAM S. KURZ, SJ \\ (Marquette University Jesuit Residence, PO Box 1881, Milwaukee, WI 53201-1881, USA)
}

\section{INTRODUCTION}

One of the cruces interpretum regarding the Acts of the Apostles that continue to reappear in scholarly discussions is why some stories are repeated three or more times. Redaction criticism moved the solutions beyond the earlier theories of multiple sources toward a consensus of attributing repetition to Lukan redaction. One contribution from redactional approaches was the awareness of how emphasis is achieved by repeating accounts of events that are especially pivotal to the overall plot of Acts. ${ }^{1}$

A related problem requiring explanation are the differences, sometimes even at least apparent contradictions of detail, among these multiple versions. Redactional solutions have tended to attribute some of these differences to the influence of diverse audiences, and some to redactional carelessness. ${ }^{2}$

The recent emergence of a third approach to the Lukan narrative, which applies contemporary literary criticism of narratives, suggests further insights into these repetitions with discrepancies, insights which appear to complement rather than conflict with the redactional solutions. Beyond the acknowledged effects that repetitions have in producing emphasis as well as variation vis-àvis different audiences, further explanation of these differences relates them to differing points of view from different narrators. ${ }^{3}$

Additional corroborating evidence for the explanation of variant repetitions by variant narrators found in the author's Reading Luke-Acts has since appeared. Narrative critical literary insights into 'functional redundancy' as explaining narrative purposes of repeated accounts provide something of a foundation for understanding repeated narratives which have varying points of

1 Cf. Ronald D. Witherup, 'Cornelius Over and Over and Over Again: "Functional Redundancy" in the Acts of the Apostles', JSNT 49 (1993) 45-66, especially with the bibliography on repetition as emphasis that he cites (p. 45, n. 2).

2 William S. Kurz, Reading Luke-Acts: Dynamics of Biblical Narrative (Louisville, KY: Westminster/John Knox, 1993) 126, 210 nn. 3-5.

${ }^{3}$ Ibid. 
view. 4 These studies of functional redundancy articulate the functions within narrative exercised by repetition with variation, especially the following five kinds of variation: expansion or addition, truncation or ellipsis, change of order, grammatical transformation, and substitution. ${ }^{5}$ Such redundancy serves a narrative strategy to correlate characterization and plot. Thus in Acts 9, 22, and 26 and 10-11, decreased emphasis on the respective minor characters of Ananias and Cornelius in the repetitions, with correspondingly increased emphasis on Paul and Peter, facilitates in the plot an intensified focus on God's action through Paul and Peter. 6

Our concern is not only with the variants in functional redundancy that are due to diverse audiences, but also with those attributable to different narrators having disparate points of view. The Peter-Cornelius account is nuanced, and not merely repeated, by the use of both the external (extradiegetic) main narrator for the original account and of the internal (intradiegetic) character narrators Peter and Cornelius to repeat the same story (as a story within the story). ${ }^{7}$

4 On repetitions in Acts, cf. especially Ronald D. Witherup, 'Functional Redundancy in the Acts of the Apostles: A Case Study', JSNT 48 (1992) 67-86, a study of the repeated accounts of Paul's conversion in Acts 9, 22, and 26; and Witherup, 'Cornelius Over and Over', which makes similar points about the repetitions of the Cornelius account.

For related narrative critical studies, see Beverly R. Gaventa, From Darkness to Light: Aspects of Conversion in the New Testament (Philadelphia: Fortress, 1986) 107-29; and Robert C. Tannehill, The Narrative Unity of Luke-Acts: A Literary Interpretation (2 vols.; Minneapolis: Fortress, 1990) 2.128-45.

5 Witherup, 'Cornelius Over and Over', 47. The only form of variation Witherup does not find regularly employed in Acts 10-11 is that of grammatical transformation (p. 62). His analysis is based on Meir Sternberg, The Poetics of Biblical Narrative: Ideological Literature and the Drama of Reading (Indiana Literary Biblical Series; Bloomington: Indiana University, 1985); see esp. 390-3.

6 Cf. Witherup, 'Cornelius Over and Over', esp. 57, 61, 63, 64-5. Classic studies of functional redundancy are Sternberg, Poetics of Biblical Narrative, esp. 365-440; and George W. Savran, Telling and Retelling: Quotation in Biblical Narrative (Indiana Studies in Biblical Literature; Bloomington: Indiana University, 1988). For redundancy in Luke-Acts, cf. Robert C. Tannehill, 'The Composition of Acts 3-5: Narrative Development and Echo Effect', SBLSP 1984 (Kent H. Richards, ed.; Chico, CA: Scholars, 1984) 217-40. For repetition in the NT and Greek rhetoric, see E. A. Nida, J. P. Louw, A. H. Snyman, J. V. W. Cronje, Style and Discourse, with Special Reference to the Greek New Testament (Cape Town: Bible Society, 1983) 22-3. On the importance of redundancy in ancient rhetoric, see Heinrich Lausberg, Handbuch der literarischen Rhetorik (2 vols.; Munich: Max Hueber, 1960) 1.310-15 (his 1973 second augmented edition was not available to me). Redundancy is also important in oral rhetoric: see Werner H. Kelber, The Oral and the Written Gospel: The Hermeneutics of Speaking and Writing in the Synoptic Tradition, Mark, Paul, and Q (Philadelphia: Fortress, 1983); Paul J. Achtemeier, 'Omne Verbum Sonat: The New Testament and the Oral Environment of Late Western Antiquity', JBL 109 (1990) 3-27.

7 Witherup, 'Cornelius Over and Over', 54, notes that when the viewpoints of various characters in the story match those of the implied author spoken by the narrator, this 
This insight from modern literary criticism is not an artificial anachronistic imposition of modern categories on ancient texts. Evidence to counter such a charge is an ancient rhetorical exercise commonly taught in Hellenistic schools, the practice of prosopopoeia. Students were taught to assume an historical or mythical persona like Caesar or Prometheus and to create speeches appropriate both for the speaker and for the occasion and audience. 8 Quintilian, a Roman rhetorician roughly contemporaneous with Luke, notes how difficult such exercises in impersonation are:

Consequently I regard impersonation as the most difficult of tasks ... [difficillimae videntur prosopopoeiae]. For the same speaker has on one occasion to impersonate Caesar, on another Cicero or Cato. [Namque idem illud aliter Caesar, aliter Cicero, aliter Cato suadere debebit. $]^{9}$

In How to Write History, Lucian describes prosopopoeia thus: 'If a person has to be introduced to make a speech, above all let his language suit his person ['̇oเkó $\tau \alpha \tau \hat{\omega} \pi \rho 0 \sigma \omega ́ \pi \omega]$ ] and his subject, . . . (\$58, LCL 6.70-1) Theon, a Greek rhetorician probably close in

reinforces the primary ideological point of view from which all others are evaluated. He refers to the classic discussion of Susan S. Lanser, The Narrative Act: Point of View in Prose Fiction (Princeton: Princeton University, 1981). For the expressions extradiegetic and intradiegetic as

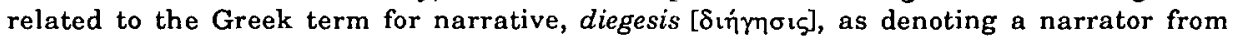
without [extra] or from within [intra] the narrative, see Kurz, Reading Luke-Acts, 206, n. 107; cf. Shlomith Rimmon-Kenan, Narrative Fiction: Contemporary Poetics (New Accents; New York: Methuen, 1983) 91-5, 103.

${ }^{8}$ See esp. William S. Kurz, 'Hellenistic Rhetoric in the Christological Proof of Luke-Acts', CBQ 42 (1980) 186; Kurz, Reading Luke-Acts, 98-9, 125-6, 128-31, 204 n. 82, 211 n. 14; Henry J. Cadbury, The Making of Luke-Acts (London: SPCK 1968 [1927]) 185-90; David E. Aune, The New Testament in Its Literary Environment (Library of Early Christianity; Philadelphia: Fortress, 1987) 125-8.

${ }^{9}$ Quintilian 3.8.49 (LCL 1.502-3) [emphasis is in the original translation]. In a different setting, Quintilian comments about the power of 'impersonation, or $\pi \rho 0 \sigma \omega \pi \circ \pi \circ$ Li $^{\alpha} \alpha$ ' [fictiones

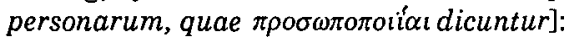

By this means we display the inner thoughts of our adversaries as though they were talking with themselves (but we shall only carry conviction if we represent them as uttering what they may reasonably be supposed to have had in their minds) [quae cogitasse eos non sit absurdum]; or without sacrifice of credibility we may introduce conversations between ourselves and others, or of others among themselves, and put words of advice, reproach, complaint, praise or pity into the mouths of appropriate persons [et suadendo, obiurgando, querendo, laudando, miserando personas idoneas damus] ... .

For my own part, I have included both [fictitious and real persons] under the same generally accepted term [prosopopoeia], since we cannot imagine a speech without we also imagine a person to utter it [Nam certe sermo fingi non potest, ut non personae sermo fingatur] (Quintilian 9.2.30-2, LCL 3.390-3).

The texts from Quintilian and from Dionysius of Halicarnassus were noted by John Lilley in early drafts of his Marquette University $1994 \mathrm{Ph}$.D. dissertation, "The Narrative Presentation of Ethical Paradigms in Dionysius's Roman Antiquities and Luke-Acts', ch. 2, 'Literary Theory: Modern and Ancient'. They include Quintilian 3.8.49-54; 6.1.26, 39-42; 9.2.29-37; and Dionysius of Halicarnassus, On Literary Composition \$20 (LCL 198-200; W. Rhys Roberts, tr.; London: MacMillan, 1910). 
time to Luke-Acts, describes prosopopoeia as creating words suitable for the person speaking and the matters treated. ${ }^{10}$ Finally, the often quoted statement from Thucydides illustrates historiographical applications of prosopopoeia:

As to the speeches that were made by different men, ... it has been difficult to recall with strict accuracy the words actually spoken, both for me as regards that which I myself heard, and for those who from various other sources have brought me reports. Therefore the speeches are given in the language in which, as it seemed to me, the several speakers would express, on the subjects under consideration, the sentiments most befitting the

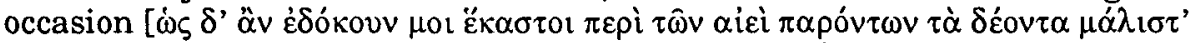

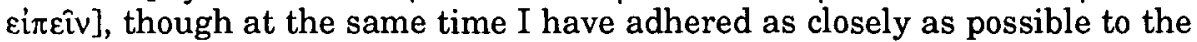
general sense of what was actually said. (Thucydides, Peloponnesian War, 1.22.1, LCL 1.38-9)

The fact that the Lukan author probably learned how to craft speeches appropriate not only to the audience and occasion (as redaction criticism has long appreciated), but also to the perspective of the particular speaker (which literary criticism analyzes under the narrator's point of view), provides warrant for applying these literary insights to the Lukan text of Acts. This paper will test the hypothesis that the repeated accounts in Acts are deliberately refocused through the viewpoints of the characters narrating them.

It is easier to verify deliberate focalizing of repeated narratives through characters' viewpoints when the differences are pronounced or even discrepancies, as in the repeated calls of Paul in Acts 9,22, and 26. Most critics have treated discrepancies like the following as careless Lukan redaction.11 Acts 9.7 says Saul's companions heard a voice but saw no one; Acts 22.9 has them seeing the light but not hearing the voice. In Acts 9.7 the companions stand speechless, but in Acts 26.14 they fall to the ground with Saul. ${ }^{12}$ But carelessness is an explanation only in the absence of all more constructive answers.

One such positive explanation is the focalizing of the repeated versions through the vantage point of Saul. The omniscient general narrator stands 'above' the action viewing the whole event. ${ }^{13}$

10 Theon Peri Prosopopoiias, Progymnasmata in Rhetores Graeci (ed. L. Spengel; 3 vols.; Leipzig: B. G. Teubner, 1854) 2.115.

11 E.g., Hans Conzelmann, Acts of the Apostles: A Commentary on the Acts of the Apostles (Hermeneia; Philadelphia: Fortress, 1987) 72-3; Gerhard Schneider, Die Apostelgeschichte 2: Kommentar zu Kap. 9,1-28,31 (HTKNT 5.2; Freiburg: Herder, 1982) 2.21-4.

12 Kurz, Reading Luke-Acts, 126.

13 See Rimmon-Kenan, Narrative Fiction, 74-7 on focalization as position relative to the story, i.e., external or internal to the story. 
But plausibility suggests that the character narrator Saul, whose attention was focused on his fall to the ground and the voice and light, is less likely than the uninvolved narrator to attend carefully to what his companions see or hear or whether they remain standing or also fall. Thus the discussions of inconsistencies by redactional and source critics find a relatively simple and plausible solution in the basic probabilities of what each respective narrator would notice and report. The knowledge of the main narrator is generally described as 'omniscient', in the sense of privileged with inside information and overviews not available to the casual observer, whereas the knowledge of any character narrator like Saul is limited to what he could know. ${ }^{14}$ For example, only the narrator can relate the simultaneous visions of both Saul and Ananias. The narrator also focalizes his account from a point of view that is inclusive of more characters, including Saul's companions and the absent Ananias. Therefore, the narrator's version carries primary authority in cases of discrepancies. ${ }^{15}$

This essay applies to the Peter-Cornelius accounts in Acts 10-11 (and 15) the same methods used to analyze the Pauline call narratives (Acts 9, 22, 26) in the author's monograph, Reading Luke-Acts: Dynamics of Biblical Narrative, chapter 8, 'Influence of Variant Narrators on Repeated Acts Narratives'. Beginning with a small control example, the narrator's version of only the Cornelius vision, it will briefly compare and contrast accounts of this vision by the main narrator with those by character narrators. Then it will compare more analytically the similar and different characteristics of all versions of the complex Peter-Cornelius event in Acts 10-11 (and 15). It will demonstrate that repeated Acts narratives, first by the extradiegetic main omniscient narrator and then by intradiegetic character narrators in Acts, acquire different nuances, not only because of differing audiences and occasions, but also because of different points of view of the diverse narrators.

\footnotetext{
14 Cf. Kurz, Reading Luke-Acts, 126-31. The term 'omniscient' can be misleading, especially when related to the theological axioms of God's omniscience and biblical inspiration as Meir Sternberg does (cf. Poetics, pp. 84-99, 179-85). But it has become a standard term in literary studies and most scholars have a common understanding of the limits of its claims.

Besides the differing kinds of knowledge available to the main and character narrators respectively, the rhetoric of persuasion also contributes to different emphases, as D. Marguerat noted in his 1994 SNTS response to an earlier version of this article. The information provided by the character narrator is often selected according to what is more effective toward persuading his or her audience.

15 See Kurz, Reading Luke-Acts, 126-31, esp. 131; cf. Sternberg, Poetics, 75-6, 130, 245-6, 380-2, 389-91, 413-18, chart pp. 432-3; Savran, Telling and Retelling, 13-15.
} 


\section{PRIMARY ACCOUNT OF CORNELIUS'S VISION BY THE MAIN NARRATOR OF ACTS}

The first version of the Peter-Cornelius incident which readers encounter is that in Acts 10 by the narrator of Acts. Since this is the first narration of the event, readers do not yet have any alternative version to prompt modifications of their original impressions. Nor to this point in the Acts narrative have they been given any reason to doubt the narrator's reliability. As is usual in the biblical narrative traditions to which Luke-Acts is correlated, the narrator's version tends to be the authoritative one. ${ }^{16}$ Later versions by character narrators within the story may nuance the audience's understanding of the Peter-Cornelius events in view of the characters' perspectives, but this authoritative version will naturally remain the primary analogate for comparisons. ${ }^{17}$

The narrator introduces the character Cornelius as someone initially quite unknown to the implied audience: 'A certain man in Caesarea, Cornelius by name.' He provides basic information on Cornelius: that he is a 'centurion of what was known as the Italian cohort, a devout man who feared God with all his household, gave alms liberally to the people, and prayed constantly to God' (Acts 10.1-2). The offhand reference to Jews as 'the people' ( $\pi 01 \hat{\omega} \mathrm{v}$ $\dot{\varepsilon} \lambda \varepsilon \eta \mu 0 \sigma v \dot{v} \alpha \varsigma \pi 0 \lambda \lambda \dot{\alpha} \varsigma \tau \hat{\varphi} \lambda \alpha \hat{\varphi})$ gives the impression that the principal narrator shares the perspective that the Jews are God's people. 18 This point of view echoes that of the Jews in Luke 7.5 who told Jesus about how worthy a centurion was because of his love of 'our

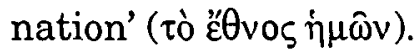

16 On the narrator's version as authoritative, see Kurz, Reading Luke-Acts, 126-31. On correlation between the Lukan and biblical narratives, see pp. 10-11, 46-7; Luke Timothy Johnson, 'Luke-Acts, Book of', $A B D$ 4.406, esp. 408; Nils A. Dahl, "The Story of Abraham in Luke-Acts' in Studies in Luke-Acts: Essays Presented in Honor of Paul Schubert (ed. Leander Keck and J. Louis Martyn; Nashville: Abingdon, 1966) 152-3.

17 See Kurz, Reading Luke-Acts, 126, 131, 210 n. 5. This does not preclude the fact that in the Peter-Cornelius event, the repeated narrations by the characters can actually present more fully the meaning of an incident that was initially experienced by Peter as confusing. Thus (developing a suggestion by David Moessner in the 1994 SNTS Luke-Acts seminar), there is a major progression in knowledge from Acts 10.20 and 11.12, where the Spirit is reported to have ordered Peter to accompany the Gentiles without discriminating $(10.20 \mu \eta \delta \dot{\varepsilon} v$

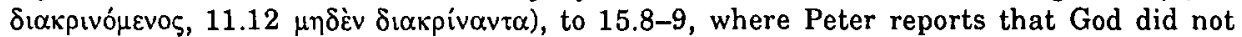

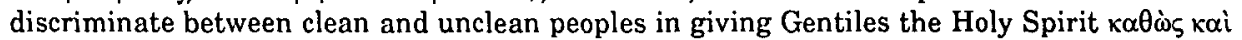

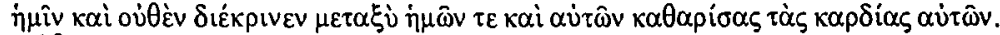

18 Since the main narrator is reliable in the sense of accurately reflecting the viewpoints of the implied author (those aspects of himself the real author allows to surface in the text), this sheds light on the implied author's positive ideological position towards the Jews as God's people. Cf. the debate in Joseph B. Tyson, ed., Luke-Acts and the Jewish People: Eight Critical Essays (Minneapolis: Augsburg, 1988). 
The narrator's point of view is omniscient, providing inside views unavailable to ordinary observers, and fully identifying whom Cornelius sees in his vision: 'an angel of God' (Acts 10.3). ${ }^{19} \mathrm{Com}-$ parison with the account by Cornelius himself yields a more immediate and impressionistic (but less literally accurate) version: 'and behold, a man stood before me in shining clothing' (10.30). Since by verse 30 the readers have already learned that this 'man in shining clothing' was an angel, the repetition can afford to give simply the first visual impression of the character.

The omniscient narrator supplies the time of prayer (about the ninth hour), and shows the angel coming in to Cornelius. Only the main narrator includes the initial dialogue between Cornelius and the angel. The angel addresses Cornelius by name. Cornelius stares at the angel, becomes afraid, and asks, 'What is it, lord?' The angel refers to Cornelius's prayers and alms ascending 'as a memorial before God', and instructs him to send men to Joppa 'to bring one Simon who is called Peter' (Acts 10.5 RSV) who is staying with Simon the tanner. This indefinite way of referring to Simon Peter and the implicit comparison of him with a second Simon the tanner accentuates that Cornelius had never heard of Simon Peter before. The narrator shows Cornelius calling two servants and a 'devout ( $\varepsilon \dot{\sigma \varepsilon} \beta \eta$ 's) soldier' after the angel left, narrating all to them and sending them to Joppa. Cornelius will simplify this account when he reiterates these events to Peter.

The most striking manifestation of the omniscience of the main narrator is his mentioning two events going on in different places at the same time, and making the transition from one, the vision of Cornelius, to the other, the vision of Peter. The narrator's unique perspective is especially evident in Acts 10.9 , when from a 'bird's eye view' he simultaneously shows (with 'split-screen' vision) both the messengers of Cornelius proceeding on the road and Peter going up on his housetop to pray 'about the sixth hour' (time for the noon meal). He then shifts full attention to Peter and his vision.

REPEATED ACCOUNTS BY CHARACTER NARRATORS:

MESSENGERS (ACTS 10.22) AND CORNELIUS (ACTS 10.30-3)

Two repetitions of Cornelius's story are narrated by characters to the character narratee Peter. The perspective and focalization repetitions observed by Tannehill, Narrative Unity, 2.130-3. 
of these reports between characters becomes much more interpersonal and limited than the narrator's original account. ${ }^{20}$ Gone are the overview perspectives, detached third-person presentation, insights into interior experiences of characters other than the narrators themselves, or narration of simultaneous but spatially separate events by the omniscient narrator.

The first repetition of the Cornelius story is a summary reprise in Acts 10.22 by messengers whom Cornelius sends to Peter. Space limits our treatment of this capsulized repetition to the following points. The character narrators reduce the story to those essentials needed to persuade Peter to come with them, as would be expected from messengers. Their perspective and knowledge is limited to those of external observers. They identify Cornelius simply by what can be perceived about him and what they deem as probably important to a Jew like Peter: his status as a centurion, that he is upright and God-fearing, and that Jews regard him highly. They also reduce the action to its barest minimum: that he 'was directed by a holy angel to send for you to come to his house'. But they add motivation not explicit in the initial account by the narrator: 'to hear what you have to say' (Acts $10.22 \mathrm{RSV}$ ).

Similar differences of perspective are noticeable when Cornelius repeats to Peter (more fully than the mere summary by the messengers) the account which the narrator had initially shown to the readers. The point of view is no longer from without, uninvolved, 'objective', but is focalized through the experience of Cornelius himself. Secondly, the audience is changed from unspecified potential readers to Peter himself, which causes different details to be mentioned. Thirdly, because the time perspective is later retrospection, the repetition includes some later developments not recounted in the initial version. By now Peter has had his own vision and has travelled to, and been greeted by, Cornelius.

Thus Cornelius begins his narration by the time reference, 'Four days ago, about this hour' (10.30 RSV). The limited point of view and individualized focus of this character narrator becomes apparent: 'I was keeping the ninth hour of prayer in my house; and behold, a man stood before me in bright apparel' (10.30 RSV). The Cornelius account focuses on the visual impression that the messenger makes on Cornelius, without the omniscient narrator's identification of this visitor as an angel of God (10.3).

\footnotetext{
20 For an explanation of the term focalization as a variation on 'point of view', see RimmonKenan, Narrative Fiction, 71-85.
} 
The character narrator simplifies the scene by omitting the initial encounter and dialogue between the angel and Cornelius to focus simply on the visitor's message: 'Cornelius, your prayer has been heard and your alms have been remembered before God. Send therefore to Joppa and ask for Simon who is called Peter; he is lodging in the house of Simon, a tanner, by the seaside' (10.31-2 RSV). Although both the main and the character narrators are quoting the messenger in direct address, the angel's words are not identical in the two accounts, but Cornelius's version is slightly simpler. One difference that is easy to explain concerns how reference is made to Peter, the listener to Cornelius's narration. Whereas the indeterminate reference by the main narrator to

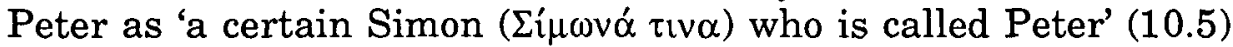
portrays Peter as unknown to the centurion, Cornelius himself quotes the angel as referring more straightforwardly to the Peter whom he is currently addressing as 'Simon who is called Peter' (10.32 RSV).

The Cornelius narrator also simplifies his response to the message and focuses it as a personal transaction between himself and his listener Peter: 'So I sent to you at once' (10.33 RSV). Speaking from his later perspective, he adds Peter's response, which had not yet occurred at the time covered in the narrator's version: 'and you have been kind enough to come' (10.33 RSV). He also adds a further reason why his household is present: "to hear all that you have been commanded by the Lord' (10.33 RSV). This echoes but also develops in a more explicitly theological manner the addition made earlier in the schematic summary account by Cornelius's messengers to Peter in Acts 10.22: 'Cornelius . . . was directed . . . to hear what you have to say' (RSV).

\section{EXTRADIEGETIC AND INTRADIEGETIC NARRATORS IN ACTS 10-11}

After the control example of these brief comparisons and contrasts among individual accounts of Cornelius's vision by the main narrator with those by character narrators, we will now do an analytic comparison of the similar and different characteristics of all versions of the complex Peter-Cornelius event in Acts 10-11 (and 15). The following comparisons can delineate the plainly different points of view between the extradiegetic omniscient narrator of Acts as a whole and the intradiegetic character narrators Cornelius and Peter in all the repeated imbedded narratives in Acts 10-11. 
Speaking from outside the story, the extradiegetic narrator normally uses the showing point of view - that is, he unobtrusively shows the action unfolding in third-person narration without comment, somewhat as a TV camera shows a game being played. ${ }^{21}$ He will not ordinarily use the telling point of view, in which the narrator is noticed as part of the story he is telling. The most common exception of extradiegetic telling is when the narrator interrupts his narration to provide an aside or explanation to the audience, as when he translates for his intended Greek-speaking audience the non-Greek name in Acts 4.36: 'Barnabas (which means, Son of encouragement)...'(RSV).

Intradiegetic character narrators, who narrate the story as an imbedded narrative within the overall narrative of Acts, use the telling point of view. The character narrator interacts with his character narratee in a direct I-you relationship in telling the latter what happened. Thus in Acts 11.4-5, the audience observe Peter responding by a narrative of his vision to Jewish Christians who objected to his eating with the uncircumcised. As character narrator, Peter's role in the narrative is obtrusive and told in the first person.

\section{OMNISCIENT VS. NON-OMNISCIENT, IDEOLOGICAL POINTS OF VIEW}

The most significant differences are between the omniscient point of view enjoyed by the extradiegetic narrator of Acts and the nonomniscient ideologically diverse points of view of various intradiegetic character narrators. Whereas the omniscient narrator describes interior viewpoints and experiences of all characters, the character narrator expresses only what he knows from his perspective as an actor in the scene.

The following examples illustrate some of the differences between the narrator's omniscience and the more restricted points of view of the characters. Whereas the omniscient narrator relates the interior visions of both Cornelius (Acts 10.3-6) and Peter (Acts 10.10-16), and shows what both the messengers and Peter are doing at the same time in different places (Acts 10.9, 17-20), Peter and Cornelius relate only their own visions.

After the main narrator showed Peter's speech to Cornelius's household in Acts 10.34-43, differences between his account of 
their reaction (10.44-8) and Peter's recollection of the same events (11.15-18) further illustrate how omniscient and restricted points of view produce different results. The first example is actually a minor discrepancy between the omniscient and a more limited character narrator. Whereas the narrator referred to the falling of the Holy Spirit on the listeners after an extended speech 'while Peter was still saying this' (10.44 RSV), Peter less accurately said it happened 'as I began to speak' (11.15 RSV). Only the narrator related the amazement of the circumcised Jerusalem Christians with Peter and gave their interior reason, because the gift of the Holy Spirit had been poured out even on the Gentiles' (10.45 RSV). Only the narrator explained why they came to this conclusion, 'For they heard them speaking in tongues and extolling God' (10.46 RSV). On the other hand, Peter narrated only his own perspective on these events: 'And I remembered the word of the Lord, how he said, "John baptized with water, but you shall be baptized with the Holy Spirit"' (11.16 RSV). The result is a different explanation for what happened, with the narrator giving the understanding of those with Peter, and Peter giving his own complementary recollection and insight.

The combination of the two perspectives in the repeated accounts by different narrators enriches the audience's understanding of the one event. Not only do they get an 'objective' third-person account from the narrator, but they receive a version of the same event from the viewpoint of a character involved in it. The narrator shows Peter giving instructions (in directly quoted address) that are similar to Peter's own recollection of his instructions, with some variations. "Then Peter declared, "Can any one forbid water for baptizing these people who have received the Holy Spirit just as we have?"' (10.46b-47 RSV). The character narrator Peter put it thus: "If then God gave the same gift to them as he gave to us when we believed in the Lord Jesus Christ, who was I that I could withstand God?' (11.17 RSV). The limited I-you perspective of Peter telling this to the Jewish Christians leads to the inclusive 'us' in 'gave to us when we believed'. In place of the more distanced thirdperson narrator's showing of Peter's response in direct quotation, Peter's own version includes both himself as narrator and his narratees in the response, and draws for them his defensive conclusion, 'who was I that I could withstand God?' which deflects 'blame' for what happened from himself to God.

A second repetition of this account by Peter at the 'Jerusalem Council' in Acts 15.7-11 contributes to an even more rounded and theological perspective on the Peter-Cornelius event. Speaking 
with even more extended retrospection, Peter interprets this event within a broader salvation history perspective. 'Brethren, you know that in the early days God made choice among you, that by my mouth the Gentiles should hear the word of the gospel and believe' (15.7 RSV). As an authentic application of the rhetoric of prosopopoeia to suit speaker, occasion, and audience, the character narrator Peter recalls and interprets what occurred from a perspective even later in the plot, with the goal of answering a controversy about whether Gentile Christians need be circumcised.

Peter's following statement echoes several aspects both from his first speech to Cornelius in Acts 10 and from his defence of his actions in Acts 11. 'And God who knows the heart bore witness to them, giving them the Holy Spirit just as he did to us; and he made no distinction between us and them, but cleansed their hearts by faith' (Acts 15.8-9 RSV). The reference to God knowing the heart recalls Peter's statements that God shows no partiality but accepts people of any nation who fear him and do what is right (Acts 10.34-5). Reference to 'giving them the Holy Spirit just as he did to us' echoes his own earlier statements in Acts 11.17 and 10.47. In Acts 15.9 Peter further interprets the Cornelius event with his conclusion about God making no distinction 'between us and them' when he cleansed their hearts by faith. His challenge to those in Jerusalem not to tempt God, 'Now therefore why do you make trial of God by putting a yoke upon the neck of the disciples . . ?' (15.10a RSV), also recalls and nuances for a new occasion his earlier statements about not preventing baptism from those who received the Holy Spirit (10.47), and 'who was I that I could withstand God?' (11.17 RSV).

Another important difference between the extradiegetic omniscient perspective and the intradiegetic character's perspective is in how the narrative is focalized. Whereas the main narrator's account is focalized from outside the scene depicted, which enables him to provide overviews, observations of simultaneous events (e.g., Acts 10.9), and sometimes even 'double visions' (as when Ananias and Paul see each other having a vision of the other in Acts 9.11-12), ${ }^{22}$ each character narrator's version is focalized through that character's perspective (as that through Peter or Cornelius). The character can only recount what he himself experiences, observes, or reasons to, as when Cornelius describes his primary and secondary sources. 
impression of the angel's appearance as 'a man stood before me in bright apparel' (Acts 10.30 RSV).

Because of this focalization of the repeated account through the character narrator Peter, the order in which the events are related is quite different. The main narrator described Peter as narrating the events in order ( $\kappa \alpha \theta \varepsilon \xi \hat{\eta} \varsigma$ Acts 11.4, cf. Luke 1.3), and Peter's order almost reverses the narrator's. The extradiegetic narrator presented first the vision of Cornelius and his sending for Peter (Acts 10.1-8), secondly Peter's vision as the messengers were approaching (10.9-16), thirdly their arrival and the Spirit's instruction to Peter to go with them (10.17-23a), fourthly Peter's meeting with Cornelius (10.23b-29).

The order of Peter's narrative corresponds instead to the order in which he himself became aware of the various incidents that make up the Cornelius-Peter event. Thus Peter narrated first his own vision (Acts 11.5-10), secondly the arrival of the messengers and the Spirit's instruction to accompany them (11.11-12), thirdly Peter's meeting with Cornelius (11.12b), and fourthly Cornelius's vision (11.13) with the added information that Peter's words ( $(\dot{\eta} \mu \alpha \tau \alpha$ ) will be for the salvation of Cornelius and his household (11.14), which specifies the messenger's 'to hear words ( $\dot{\eta} \eta \mu \alpha \tau \alpha)$ from you' (10.22).23

Despite the deepening insight repetitions by later character narrators provide to the narrator's initial account, the omnisicient point of view of the reliable extradiegetic narrator enjoys a presumption of accuracy that a character narrator does not have, unless that character also happens to be reliable in the sense of relating what is in accord with the viewpoint of the implied author. But in minor details even reliable characters are liable to mistakes due to their limited perspectives and knowledge, so that when there are discrepancies between accounts by the main narrator and character narrators, the presumption of accuracy goes to the main narrator. ${ }^{24}$ The discrepancy between when the narrator and when

23 At my presentation of this material 2 August 1994 at the SNTS meeting in Edinburgh, Robert Tannehill pointed out the different order in which the events are narrated, corresponding to the different order in which Peter experienced them. He and Mikeal Parsons noted that Peter's increasing awareness of the meaning of the earlier events moves the plot along and approximates the implied author's perspective more closely than the narrator's initial version had. For evidence and debates about the kind of order implied in $\kappa \alpha \theta \varepsilon \xi \hat{\eta} \zeta$ in Acts 11.4 (cf. Luke 1.3), see esp. Martin Völkel, 'Exegetische Erwägungen zum Verständnis des Begriffs $\kappa \alpha \theta \varepsilon \xi \hat{\eta}$ im lukanischen Prolog', NTS 20 (1973/4) 289-99 (esp. 294 and 298); and Joseph A. Fitzmyer, The Gospel according to Luke (I-IX): Introduction, Translation, and Notes (AB 28; Garden City, NY: Doubleday, 1981) 1.298-9, 301-2.

24 See note 15 above. The rhetoric of persuasion can also lead to emphases based more on convincing an audience than on simply relating facts. 
Peter said the Holy Spirit fell on Cornelius's household exemplifies this. In Acts 10.44, the narrator said that this occurred after Peter's summary of Jesus's life, death, and resurrection. 'While Peter was still saying this' (10.44 RSV) gives the impression that the Spirit broke in as Peter was nearing the end of his speech. But in Acts 11.15, Peter said the Spirit fell as he began to speak. Here the readers of Acts would be expected to accept the omniscient narrator's previous account as accurate, easily interpreting Peter's version as a slightly imprecise abbreviation for rhetorical purposes of what they had already heard reported by the narrator. ${ }^{25}$

Another major advantage of the omniscient over more particular points of view is that it is not temporarily restricted to the event being recounted, but it can refer backward or forward to any point in the plot from beginning to end, and can even refer to events that take place after the plotted end of the narrative (e.g., the fall of Jerusalem after Paul's final statement in Acts 28). A character narrator like Cornelius or Peter is temporarily restricted to the moment in the plot when he is narrating or backward in retrospection. Only by means of conjecture or prophecy can he narrate what has not yet occurred.

Thus both the main narrator and character narrators can include in their accounts anterior causes that have led up to the events currently being recounted (to the extent of characters' awareness of these causes). But only the main narrator can incorporate future events as he describes the present action (as when the Lukan narrator refers to the child John being in the wilderness 'till the day of his manifestation to Israel' [Luke $1.80 \mathrm{RSV}$ ]). The only way characters can narrate occurrences subsequent to their speaking is by conjecture or prophecy about the future ('I tell you, Peter, the cock will not crow this day, until you three times deny that you know me', Luke 22.34 RSV).

Another important difference in point of view between an omniscient narrator and character narrators is that the omniscient narrator's perspective (as reliable) is expected to be closely related

\footnotetext{
25 The focus of the narration by the character Peter is exclusively on God's action of giving the Spirit, not on his preceding speech. This exclusive focus on God's action serves his rhetorical purpose of persuading Jewish Christians by answering their objections to his eating with the uncircumcised (11.3). By emphasizing God's intervention exclusively, he persuades them, "Then to the Gentiles also God has granted repentance unto life"' (11.18 RSV). The opposite emphasis on Peter's instrumentality is stressed in Peter's report to the 'Jerusalem Council': 'Brethren, you know that in the early days God made choice among you, that by my mouth the Gentiles should hear the word of the gospel and believe' (15.7 RSV). The main contributors of these suggestions during the 1994 SNTS discussion were David Moessner, Camille Focant, Daniel Marguerat, and Max Turner.
} 
to that of the (implied) author, whereas the character narrators speak from the subordinate perspectives of those characters (Cornelius or Peter), not necessarily that of the author. However, we have seen that additions later in Acts by the reliable character narrator Peter can bring out the deeper meaning of events more closely approximating the implied author's perspective than the original account by the omniscient narrator (cf. Peter's versions in Acts 15.8-9 and 11.15-17 with the narrator's in 10.44-7).

Although all narration is retrospective because one cannot narrate an event (or phase of an event) until that event or phase is completed, repeated narration necessarily involves later retelling and even further temporal retrospection. Thus Cornelius's narrative about his vision includes the later response by Peter, which occurred at a point subsequent in time and in the plot to the original vision (Acts 10.33).

The one instance where one might not expect differences in narratives by the main narrator and repetitions by character narrators is in direct quotation. Since both kinds of narrators are quoting what someone said earlier, the content of that quotation is more stable than other details in a repeated narrative. However, even here variants occur in the repeated version, often to lessen repetitiveness so as to avoid boredom. There are several minor variations in wording or perspective between the original narrator's quotation of a character and the later versions of the same direct address by Cornelius and Peter. For example, in Acts 10.14, the narrator quotes Peter as saying, 'for I have never eaten anything that is common or unclean' (RSV); in Acts 11.8 Peter quotes himself thus: 'for nothing common or unclean has ever entered my mouth' (RSV). Such repetition with deliberate variation occurs more often in written than in oral narratives, because oral narratives depend more on formulaic expressions repeated verbatim as an aid to the story-teller's memory. ${ }^{26}$

\section{CONCLUSIONS}

This paper demonstrated that it is normal in repetition of ancient narratives to nuance the repetitions with variations arising from the varying perspectives of the different narrators, not only

\footnotetext{
26 See esp. Walter Ong, Orality and Literacy: The Technologizing of the Word (New Accents; New York: Methuen, 1982) chap. 3, 'Some Psychodynamics of Orality', 31-77; chap. 4, 'Writing Restructures Consciousness', 78-116. Ancient rhetoric and historiography encouraged rewriting the words of previous speakers in one's own style. See esp. Cadbury, Making of Luke-Acts, 156-68.
} 
because of differing audiences and occasions. It illustrated those variations due to the variant narrators of repeated narratives in Acts 10-11 (and 15). Whereas the omniscient extradiegetic narrator unobtrusively 'showed' the visions, actions, and interrelationships of Cornelius and Peter, the respective character narrators Cornelius and Peter were prominent parts of the stories they told. They used the 'telling' point of view in an I-you relationship with the characters to whom they told their own story with first-person narration.

Whereas the main narrator's point of view was omniscient, those of Cornelius and Peter as character narrators were limited to the knowledge and perspectives and rhetorical purposes of their respective characters. Thus the narrator described the interior thoughts and experiences of all the characters, whereas Cornelius and Peter related only their own experience or what could be observed. The narrator focalized his third-person narration from outside the action, providing overviews or views of simultaneous events like the approach of the messengers and Peter's beginning to pray. The character narrators Cornelius and Peter focalized their first-person narration through their own perception. For example, Cornelius referred to the messenger, whom the narrator had previously and correctly identified as 'an angel of God' (10.3), according to his immediate perception thus: behold, a man stood before me in bright apparel' (Acts $10.30 \mathrm{RSV}$ ). In cases of minor discrepancies between accounts by the narrator and by characters, the presumption of accuracy went to the omniscient narrator, as when he placed the time of the Spirit's coming on Cornelius's household after an extended speech 'while Peter was still saying this' (10.44 RSV), rather than to the character Peter who timed it 'as I began to speak' (11.15 RSV). As omniscient and outside the story line, the main narrator is not as restricted to narrating only the actual event but can refer forward to what will happen later as well as backward. The characters can only look backward from their point in the plot line, except for forward-looking conjectures or prophecies.

The primary narrator has the dominant perspective, which in Acts bears a close relationship to the perspective of the implied author. The perspectives of the character narrators like Peter and Cornelius are restricted to the perspectives appropriate to those characters, which are not necessarily those of the author. Yet repetitions by reliable narrators like Peter can contribute further perspectives more finally approximating the implied author's than the initial report by the primary narrator provided. 
Because the characters in Acts 10-11 and 15 repeat earlier narratives by the main narrator, their temporal focalization is later, and they therefore can include later events like Peter's response to Cornelius's invitation (10.33).

Finally, although one might expect direct quotation by both the narrator and characters to lack variation, minor variants occur even here, probably for the sake of written variety. 